\title{
Agency conflicts, executive compensation regulations and CEO pay-performance sensitivity: evidence from Sweden
}

\author{
Katarzyna Cieślak ${ }^{1}$
}

Published online: 19 March 2018

(C) The Author(s) 2018

\begin{abstract}
Based on a unique country set up with concentrated ownership of firms, strong representation of major shareholders on boards and one of the highest percentages of firms with dual-class shares worldwide I study CEO pay-performance sensitivity in Swedish listed firms in the years 2001-2013. Focusing on Type II agency conflict, I find that that pay-performance sensitivity in family-controlled firms with family CEOs is significantly lower than in other types of firms, and that dual-class firms have significantly lower sensitivity of pay to accounting performance than non-dual-class firms. The results suggest that in firms with type II agency conflicts compensation practices may be driven either by family ties or by the power preferences of the controlling shareholder that uses compensation to align CEO's interest with his/her will rather than with financial performance. The study also documents that the link between CEO pay and performance disappears in the 2010-2013 period following the implementation of the European Recommendations regarding executive compensation. This finding is in contrast to the stipulated goal of the European Commission, 'to ensure pay for performance' (European Commission 2009).
\end{abstract}

Keywords Type II agency conflict $\cdot$ Executive compensation $\cdot$ Executive compensation regulations $\cdot$ Pay-performance sensitivity $\cdot$ Sweden

Katarzyna Cieślak

katarzyna.cieslak@fek.uu.se

1 Department of Business Studies, Uppsala University, Kyrkogårdsgatan 10, Uppsala, Sweden 


\section{Introduction}

Disclosure of executive compensation has increased significantly in Europe over the last decade since the incorporation of the European Commission (EC) Recommendations of $2004 / 2005^{1}$ and $2009^{2}$ into the corporate governance codes or national laws of the member states. As stipulated by the EC 'an appropriate remuneration policy should ensure pay for performance' (EU 2009), and 'pay for performance' was the ultimate goal of the recommendations (ibid).

In the context of ownership and corporate governance, regulation plays an important role in addressing two types of agency conflicts that may arise in firms. In the Anglo-Saxon countries such as the U.S. where relatively dispersed ownership structures exist (La Porta et al. 1999), Type I agency conflicts between managers and shareholders may arise (Jensen and Meckling 1976; Shleifer and Vishny 1997). Linking pay with performance can mitigate such conflicts by substituting for shareholder monitoring of management (Conyon 2006; Gao and Li 2015). However, the latest financial crisis showed how compensation practices are potentially abused (Faulkender et al. 2010). One major aim of the 2010 Dodd-Frank act was thus more stringent regulation concerning CEO pay-performance link. In continental Europe, ownership concentration and family ownership trends are much higher than in the US (La Porta et al. 1999; Faccio and Lang 2002). Managers are less likely to expropriate firm value due to control from the major owner. However, Type II agency conflicts between controlling and non-controlling shareholders may arise (Shleifer and Vishny 1997; La Porta et al. 1999). Controlling shareholders could be driven by private benefits (Cronqvist and Nilsson 2003) and they could use pay practices to align managers' interests with their own will rather than with financial performance. In this situation, pay-performance sensitivity may be desirable from the point of view of protecting the interests of non-controlling shareholders. In this article, I study how Type II agency conflicts potentially impact compensation practices in firms. I focus on two circumstances where Type II agency conflicts can be the most relevant: family-controlled firms where the CEO is the member of the family and firms with dual-class shares (Cronqvist and Nilsson 2003). I use a sample of Swedish listed firms (2465 firm-year observations from the Stockholm Stock Exchange for years 2001-2013), characterized by the 'active ownership' corporate governance model of strong owners who control board of directors (Carlsson 2007; The Swedish Corporate Governance Code 2015), ${ }^{3}$ and one of the highest worldwide usage of

\footnotetext{
1 2004/913/EC. Commission Recommendation of 14 December 2004 fostering an appropriate regime for the remuneration of directors of listed firms.

2005/162/EC. Commission Recommendation of 15 February 2005 on the role of non-executive or supervisory directors of listed companies and on the committees of the (supervisory) board.

2 2009/385/EC. Commission Recommendation of 30 April 2009 complementing Recommendations 2004/913/EC and 2005/162/EC as regards the regime for the remuneration of directors of listed firms.

3 In Sweden, firm owners appoint a nomination committee, a drafting body for the annual shareholders' meetings, which engages itself in the nomination process for board of directors and auditors (SCGB 2015). Only one executive is allowed to sit on the board (it is usually the CEO) and only at least two board directors are required to be independent from the main owner (ibid.). Consequently, representatives of major shareholders often sit on the boards of directors and take strategic decisions.
} 
dual class shares (Faccio and Lang 2002; Cronqvist and Nilsson 2003; Institutional Shareholder Services 2007). The Swedish context could be seen as typical for Type II agency conflicts.

Previous research on CEO pay practices in Europe document a significantly lower CEO pay in family-controlled firms (Croci et al. 2012; Collin et al. 2014), or controlled firms (Barontini et al. 2017). ${ }^{4}$ The current study complements this European evidence by investigating whether the CEO is a family member or a professional, and by studying CEO pay-performance sensitivity, i.e. how strongly pay is linked with realized performance (Gao and Li 2015; Ferri and Maber 2013; Clarkson et al. 2011). There is some evidence that family-controlled firms use a smaller fraction of equity-based compensation (Croci et al. 2012; Barontini et al. 2017). However, the structure of pay can be essentially different from pay-performance sensitivity. For example, a large bonus fraction ${ }^{5}$ is not necessarily an indication of a stronger link between pay and performance, as the decision about the size of the bonus can be a subjective choice made by the board or its compensation committee. I find that family-controlled firms with family CEOs pay significantly less to their CEOs than family firms with professional CEOs. Concurrently, they also have significantly lower pay-performance sensitivity. This indicates that CEO pay in these firms is not driven by performance, in contrast to the family-controlled firms with professional CEOs and firms with other owners (including industrial, institutional and foreign).

This study also adds to previous research by investigating dual-class shares as a potential driver of CEO pay. Previous research documents a positive association between the level of CEO compensation and dual-class shares (Masulis et al. 2009; Amoako-Adu et al. 2011; De Cesari et al. 2016). In this paper, I investigate the potential impact of dual-class shares on pay-performance sensitivity. The study results provide some evidence that dual-class shares status significantly decreases sensitivity of CEO pay to accounting performance.

The main second question asked in the study concerns how the changing regulatory environment and executive compensation disclosure impacts CEO pay-performance sensitivity. Most studies from Anglo-Saxon countries report an increase in pay-performance sensitivity following the introduction of disclosure laws (Vafeas and Afxentiou 1998; Clarkson et al. 2011; De Franco et al. 2013). However, evidence from Europe is rather scarce. The study sample spans a period of 13 years (2001-2013), and analysis over time indicates that pay-performance sensitivity holds in the early period (2001-2009), whereas the period after regulations were fully implemented (2010-2013) is characterized by homogenous pay driven by determinants other than performance, most notably the firm size. These results are

\footnotetext{
4 While this finding is interpreted as lack of direct expropriation of value from minority shareholders through excess CEO compensation, previous literature offers also a contradictory evidence. For example, Cohen and Lauterbach (2008), based on evidence from Israel, report a significantly higher pay to the owner CEOs than to nonowner professional CEOs, and in connection to board compensation Barontini and Bozzi (2011) show that board compensation in Italian firms is significantly higher when the founder of the firm seats on the board.

5 Bonuses remain the main component of performance-based pay in Sweden (Hallvarsson and Halvarsson 2011; Fernandes et al. 2013).
} 
contrary to what was found in Anglo-Saxon countries. I interpret the findings in light of an egalitarian Swedish culture with emphasis on team work rather than on 'star performers' (Holmberg and Åkerblom 2012), where more openness about compensation levels leads to more homogenous pay among the CEOs. When investigating level of disclosure specifically I do not find any evidence that higher compliance with disclosure rules positively affects pay-performance sensitivity. The results suggest that impact of regulations concerning compensation practices cannot be understood in detachment from the environment in which the changes happen (Melis et al. 2015; Van Essen et al. 2012).

The paper is organized as follows. Section 2 outlines the hypothesis development; Sect. 3 describes the regulatory changes and statistical models of the study; Sect. 4 presents the results; and finally, Sect. 5 provides a discussion and concludes the paper.

\section{Hypothesis development}

\subsection{Family-controlled firms, dual-class shares and CEO pay-performance sensitivity}

Two main perspectives that explain CEO pay are the 'optimal contracting' and 'managerial power' theories. According to the 'optimal contracting' theory CEO pay is one solution to the agency problem between managers and shareholders (Jensen and Murphy 1990, 2010; Core et al. 2001; Conyon 2006). While managers, unlike shareholders, are usually risk-averse and more inclined towards fixed pay (Jensen and Meckling 1976; Devers et al. 2008; Elsaid and Davidson 2009), ${ }^{6}$ linking CEO pay with firm's financial performance creates incentives towards creating shareholder value. CEO pay can thus substitute for shareholder monitoring. Previous research within the optimal contracting paradigm finds, for example, that ownership concentration is associated with lower pay-performance sensitivity (Ke et al. 1999; Gao and Li 2015). In contrast, the 'managerial power' theory suggests that powerful managers with ties to the board may exacerbate agency problems by abusing the contracting environment and extracting rents in the form of excessive compensation (Bebchuk and Fried 2003, 2004; Muslu 2010; Morse et al. 2011). In line with this theory, research by Elsaid and Davidson (2009) finds that high bargaining power of newly appointed CEOs vis-à-vis board (as measured by chosen CEO and board characteristics) is linked with greater proportion of salary in total pay.

Both 'optimal contracting' and 'managerial power' theories on executive compensation originate within the Anglo Saxon context, where type I agency conflict is especially pervasive due to mostly dispersed ownership structures of listed firms (Croci et al. 2012). In continental Europe and in other contexts with concentrated ownership structures and stronger presence of family control (Faccio and Lang

\footnotetext{
6 Meta-analysis studies document an overall weak statistically significant positive relation between pay and performance (Tosi et al. 2000; van Essen et al. 2012).
} 
2002; Courteau et al. 2017) controlling shareholders may limit expropriation by managers through monitoring. Controlling shareholders may also provide stability and continuation of strategy, whilst concurrently creating agency conflicts of type II between controlling and non-controlling owners (Shleifer and Vishny 1986, 1997; Faccio and Lang 2002; Cronqvist and Nilsson 2003; Barontini et al. 2017; Courteau et al. 2017). Such conflicts include direct expropriation of value from minorities, for example through related party transactions (Enriques 2015; Courteau et al. 2017), or distorted decisions about firm size, investment decisions, or transfer of control (Claessens et al. 2002; La Porta et al. 2002; Cronqvist and Nilsson 2003; Masulis et al. 2009). The concerns about non-optimal decisions are especially pertinent when controlling shareholders use dual-class shares ${ }^{7}$ (Bebchuk et al. 2000; Cronqvist and Nilsson 2003; Masulis et al. 2009). In the presence of divergence between voting and cash flow rights, controlling shareholders internalize only a fraction of negative corporate valuation consequences in case of value destroying decisions (Cronqvist and Nilsson 2003). In contexts characterized by concentrated control, I suggest a 'controlling shareholder power' perspective on CEO compensation.

Several studies document impact of family control on compensation practices in firms. Cohen and Lauterbach (2008) report significantly higher pay to the CEO when he/she is a family member and Barak et al. (2015) find the 'excess' pay is negatively correlated with end of period Tobin's Q when CEO is the family member. This is interpreted as expropriation of value by controlling shareholders through excessive pay. In a similar vein, Barontini and Bozzi (2011) find a positive association between high board compensation and the proportion of family members on board. Conversely, Croci et al. (2012) and Collin et al. (2014), document a lower pay level for CEOs in family-controlled firms. They interpret the finding as a lack of expropriation of value in family-controlled firms (Croci et al. 2012), or even a better governance in these firms compared to firms with other owners (Collin et al. 2014). Similarly, Gomez-Mejia et al. (2003) find that compensation of family CEOs is lower than of non-family CEOs. However, lower CEO compensation in familycontrolled firms overall, or for family CEOs in particular, can be a consequence of higher job security enjoyed by the CEOs, especially when they are members of the owner family (Gomez-Mejia et al. 2003). Similarly, a smaller fraction of equitybased pay for family CEOs may result from an already high ownership of the company shares by the CEO. By the same token, I suggest that family ties between family owners and CEOs shelter family CEOs from decreased compensation in case of poor financial performance. In result, pay-performance sensitivity is lower, ceteris paribus, in family-controlled firms with family CEOs. While according to the 'managerial power' theory managers with power influence the compensation process, here what matters is the biological and social factor in the form of the family tie.

H1 Pay-performance sensitivity in family-controlled firms with family CEOs is significantly lower than in other family-controlled firms.

\footnotetext{
7 Dual-class shares grant their holders more votes (usually ten) compared with ordinary shares (one vote).
} 
While family ties are theorized to have the most impact on CEO pay in familycontrolled firms with family CEOs, theoretical predictions about CEO compensation may depend more on the presence and use of dual-class shares in the context of other types of firms, including family-controlled firms with professional CEOs. Dual-class shares serve as a proxy for controlling shareholder preferences regarding strength of control. The divergence between voting and cash flow rights implies that the controlling shareholders value the control more than the cash flows rights stemming from ownership. Controlling shareholders may use compensation to endorse their preferred course of action and align CEOs interests with their own, even at the expense of divergence from minority interests. Previous research documents a positive association between the level of CEO compensation and dual -class shares status (Masulis et al. 2009; Amoako-Adu et al. 2011; De Cesari et al. 2016). In this paper, I instead investigate pay-performance sensitivity in relation to dual-class shares. Besides direct expropriation to gain loyalty of the CEO, type II agency conflict concerns non-optimal decisions driven by the controlling shareholder, which may decrease company value, as mentioned earlier (Claessens et al. 2002; La Porta et al. 2002; Cronqvist and Nilsson 2003; Masulis et al. 2009). The voting wedge implies high involvement of the major shareholder in decision making. Poor financial performance does not necessarily lead to lower compensation in cases where the CEO in essence implements decisions taken by the controlling shareholders; neither would good financial performance result in increased compensation. In result, payperformance sensitivity is lower, ceteris paribus, in dual-class shares firms. CEO pay in these firms may reflect the alignment with the will of the controlling shareholder rather than with financial performance. ${ }^{8}$ While according to the 'managerial power' theory managers with power influence the compensation, in dual-class shares firms it is the 'controlling shareholder's power' that matters.

H2 Pay-performance sensitivity is significantly lower in firms with dual-class shares than in firms with single-class shares.

\subsection{Executive compensation regulations and pay-performance sensitivity}

The 2004 EC Recommendation focused on disclosure of executive compensation. It included guidelines concerning a clear and comprehensive disclosure of the company's remuneration policy, as well as individual directors' pay and its components. Additionally, the recommendation introduced a requirement that any share-based programs needed approval through the annual general meeting and a mandatory or voluntary vote over the remuneration statement. The 2009 EC Recommendation, focused on guidelines concerning the remuneration process, rather than on its disclosure. It included requirements for the creation of a separate remuneration committee, independence of remuneration consultants, linking

\footnotetext{
8 Another potential argument toward weaker pay-performance sensitivity of CEO pay is that financial gains/losses to the controlling shareholder from his/her decisions are also disproportionally low given divergence between voting and cash flow rights.
} 
variable pay with predetermined and measurable performance criteria, vesting period for share-based remuneration, or clawback provisions.

All the requirements introduced by the 2004 and 2009 EC recommendations aim at the eradication of reward for failure or reward for luck, and seek to ensure a tighter linkage between pay and performance. These regulatory implementations thus allow for an investigation into how pay-performance sensitivity has changed over time. Previous research document increased pay-performance sensitivity in other countries. For example, Clarkson et al. (2011) document an overall increase in pay-performance sensitivity over the years 2001-2009, the study window covering important changes in executive compensation regulations in Australia. Ferri and Maber (2013) use UK data and show that 'say on pay' regulations increased sensitivity of pay to poor realizations of performance. I thus hypothesize that as result of the implementation of the EC recommendations pay-performance sensitivity increased in Sweden.

H3 Pay-performance sensitivity is the highest in the period of 2010-2013 following implementation of the European Commission recommendations.

The executive compensation recommendations included several channels of impact aimed at increased 'pay for performance', namely disclosure, guidelines concerning remuneration process and pay structure (European Commission 2009). The impact of disclosure on pay-performance sensitivity has been studied specifically by previous studies in the Anglo-Saxon context. Clarkson et al. (2011) argue that disclosure of remuneration details may lead companies to reassess their compensation packages to ensure that they are aligned with performance. They show that disclosure significantly and positively increases the slope of performance in the CEO pay regression (ibid). Vafeas and Afxentiou (1998) find that after introduction of the compensation disclosure rule by SEC in the USA in 1992 the pay-performance sensitivity increased. Both accounting and stock performance explained CEO pay variation to a significantly higher degree when compared to the period before the rule was implemented. Zhou and Swan (2006) find similar results in their study of the regulatory effects introduced in Canada in 1993; after the implementation of the new disclosure requirements, the pay-performance relationship strengthened. In the context of voluntary disclosure, De Franco et al. (2013) document stronger pay-performance sensitivity for firms that issue management guidance. Disclosure of corporate information elicits control from outside stakeholders and strengthens corporate governance through putting pressure on remuneration committees to improve the alignment between pay and performance (Vafeas and Afxentiou 1998; Zhou and Swan 2006; Clarkson et al. 2011; De Franco et al. 2013; Leuz and Wysocki 2015). In many European countries, including Sweden, the European Recommendations were incorporated in corporate governance codes. These codes function on a "comply or explain' basis. I hypothesize that firms that comply with the disclosure rules to a higher extent, show stronger pay-performance sensitivity. 
H4 Disclosure of executive compensation positively affects pay-performance sensitivity.

\section{Sample selection and empirical models}

\subsection{Regulatory environment for executive compensation in Sweden}

The Swedish regulatory setting concerning executive compensation largely mirrors the EC recommendations, with some regulatory reforms implemented even before the recommendations were issued. Already in 1993, Swedish listing rules obliged large listed firms to disclosure the total of compensation to the CEO and the board. The following regulatory events were introduced in the previous decade concerning disclosure and practice of executive compensation:

\section{1 .12003}

The new NBK rules $^{9}$ became binding for listed firms when the Stockholm Stock Exchange included fulfillment of these rules in the listing requirements. The new NBK rules specifically required disclosure of the following items: (1) all material components of the pay of the CEO; (2) the CEO's pension program and pension costs; (3) severance program and pay to the CEO; (4) and holdings of financial instruments received by the $\mathrm{CEO}$ and board members and valuation of such instruments at award. While earlier CEO and board member compensation was typically disclosed as a summary figure, the introduction of the new NBK rules added much more detail to the disclosure.

\section{1 .22005}

The newly formed Swedish Corporate Governance Board issued the Swedish Corporate Governance Code (the Code) in 2005. Functioning on a 'comply or explain' basis, the Code applied only to the largest firms until 2008, after which it applied to all listed companies. In addition to repeating the disclosure rules included in the NBK regarding systems of variable compensation to top executives and all outstanding share and share-price incentives schemes for top executives, the Code also introduced guidelines concerning process of executive compensation setting. This included the requirement of an approval of any share-based programs by the annual general meeting and a voluntary vote of the annual general meeting over the remuneration policy. ${ }^{10}$ In 2005 Sweden also adopted IFRS. IFRS 2 included recognition

\footnotetext{
9 The word NBK comes from the Swedish 'Näringslivets Börskommitté', a committee created by large Swedish listed firms aimed at formulating best practice rules. In 2010 NBK ceased to exist; its competences were taken over by the Swedish Corporate Governance Board, the issuer of the Swedish Corporate Governance Code.

${ }^{10}$ The mandatory 'say on pay' on remuneration policy was transferred later on to the Swedish Companies Act.
} 
of share-based compensation in the financial statements, which required valuation on the balance sheet date, not only on the allotment day.

\subsubsection{6}

General disclosure regulations were included in the Annual Accounts Act (AAA). Additionally, in 2006, the Swedish Stock Exchange issued in its listing rules a voluntary template for the note in the financial statements on executive compensation. This several-page template included a table with: (1) all the components of remuneration separately for CEO, other top executives and each board member; (2) a comprehensive discussion on detailed criteria for bonus with targets to be achieved for bonus; (3) maximum bonus; and (4) achieved bonus. Many firms followed the template in their notes to the financial statements. The template increased the detail of firms' descriptions of system of executive compensation in their financial statements.

\subsubsection{0}

The Code was amended following the recommendation of 2009. The amendments included independence of compensation consultants, linking variable compensation to predetermined and measurable performance criteria, limits regarding the total variable compensation, deferring parts of compensation. Sweden was one of the few countries that did not include clawbacks in the regulatory environment for executive compensation (European Commission 2010).

\subsection{The sample}

The empirical study relies on data from all Swedish firms listed on the OMX Nasdaq Stockholm Stock Exchange in the years 2001-2013. This study period covers the important changes in regulations on executive compensation disclosure and practice. Initial sample is composed of 3420 firm-year observations. The following exclusions have been made from the sample: firms not domiciled in Sweden (207 firm-year observations, as compensation practices in these firms may be influenced by other institutional settings); financial firms (268, these firms being subject to different regulations), firm-year observations with CEO turnover (472 firm-year observations, due to confounding effects of compensation/severance payments to more than one individual), missing performance data for 8 observations. The final sample consists of 2465 firm-year observations. Accounting and capital market data was obtained from the Thomson Reuter's Eikon database. Ownership groups were made according to data obtained from SIS Ägarservice AB's publications (Fristedt and Sundqvist 2001-2009, Sundqvist 2010-2013) based on identity of the largest firm owner. Data on executive compensation, disclosure of executive compensation, and dual-class shares status was manually collected from the annual reports. 


\subsection{Empirical models}

I start empirical analysis with estimating a generic firm-fixed effects regression model of CEO pay on stock and accounting performance and other economic drivers for subsamples of firms with different owners and CEO status. To test H1 I employ a specific version of the model with an interaction variable (a similar approach is used by $\mathrm{Gao}$ and $\mathrm{Li} 2015$ ) to capture how the slope of performance is affected by CEO status in family-controlled firms (1):

$$
\begin{aligned}
\operatorname{Ln}(\text { CEOPay })= & \beta 0+\beta 1 \text { CEOFamily }+\beta 2 \text { Stock } \operatorname{Re} t+\beta 3 \text { ROA } \\
& +\beta 4 \text { CEOFamily } * \text { Stock } \operatorname{Re} t+\beta 5 \text { CEOFamily } * \text { ROA } \\
& +\beta 6 \text { LogTotA }+\beta 7 \text { MktBook }+\beta 8 \text { OwnCEO }+\beta 9 \text { OwnConc } \\
& + \text { Year Dummies }+ \text { Industry Dummies }+\varepsilon
\end{aligned}
$$

Ln(CEOPay) - the natural logarithm of CEO including salary, bonus, share grants, pension, and other compensation (e.g. relocation allowance, firm car, additional insurance). ${ }^{11}$

CEOFamily - a dummy variable which takes value of 1 when the CEO is a member of the family that is the largest owner of the firm.

StockRet-annual stock price return.

$R O A-$ annual return on assets.

CEOFamily_StockRet_-an interaction variable between CEOFamily and StockRet variables.

CEOFamily_ROA—an interaction variable between CEOFamily and ROA variables.

LogTotA-logarithm of total assets (a positive effect of firm size on CEO pay has been documented by Clarkson et al. 2011; Matolscy and Wright 2011; Gao and Li 2015),

MktBook - the ratio of market-to-book value of equity, a proxy for growth opportunities, (a negative association between market-to-book and CEO pay has been documented by Clarkson et al. 2011),

OwnCEO - the percentage of the firm's equity owned by the CEO (a negative association between CEO ownership and CEO pay has been documented by Core et al. 1999; Clarkson et al. 2011; Gao and Li 2015),

Own_Conc_- the percentage of cash flow rights controlled by the largest shareholder (a negative association with CEO pay has been documented by Collin et al. 2014).

I use firm-fixed effects estimations to control for any omitted correlated variables not yet captured in the model. I also include year and industry dummies to control

\footnotetext{
11 Valuation of options was not disclosed before year 2006 and to ensure comparability in analysis options are not included in the compensation figures. Options' value in years 2006-2013 (untabulated) does not exceed five per cent of total compensation. The main variable compensation component in Sweden remains the bonus (Fernandes et al. 2013; Hallvarsson and Halvarsson 2011).
} 
for year- and industry- differences in compensation. All continuous variables are winsorized at 1 st and 99 th percentiles.

To test H2 I estimate the following firm-fixed effects regression model with an interaction variable to capture how the slope of performance is affected by a firm's dual-class status (2):

$$
\begin{aligned}
\operatorname{Ln}(\text { CEOPay })= & \beta 0+\beta 1 \text { Dual }- \text { class }+\beta 2 \text { Stock } \operatorname{Re}+\beta 3 R O A+\beta 4 \text { Dual } \\
& - \text { class } * \text { Stock } \operatorname{Re} t+\beta 5 \text { Dual }- \text { class } * \text { ROA }+\beta 6 \text { LogTotA } \\
& +\beta 7 \text { MktBook } \beta 8 \text { OwnCEO }+\beta 9 \text { OwnConc }+ \text { Year Dummies } \\
& + \text { Industry Dummies }+\varepsilon
\end{aligned}
$$

Dual-class is a dummy variable which takes value of 1 for firms that use dual-class shares. Other variables used are the same that in Eq. (1).

In connection to H3 I partition the sample and estimate regressions of CEO pay for different time periods. As the latest changes in regulatory environment were implemented in 2010, I compare the post-period of 2010-2013 with the earlier years 2001-2009. Due to shorter time panels (especially in the post-period) I use OLS estimations with clustered standard errors at firm level, instead of firm-fixed effects estimations.

Disclosure of executive compensation increases significantly between years 2001 and 2013 due to new regulations, but compliance with the regulations differs among the firms. To capture the difference in disclosure behavior among firms I create a COMPLIANCE rank variable which divides the firms in seven quintiles on a yearly basis based on a disclosure index score. The disclosure index score (DISCINDEX) has been developed in another study by Cieslak et al. (2016) and it is composed of seven disclosure items manually collected from the annual reports of the sample firms (see "Appendix" for description of the sub-items). The index is rather crude, as compared with indexes used in similar studies (e.g. Melis et al. 2015 or Barontini et al. 2017). It captures compensation items (the seven items are based on new NBK regulations) rather than compensation process (policy) and governance disclosure (as in Barontini et al. 2017), however, the cross-sectional variability of governance and process (policy) disclosure is deemed low in the study sample. The disclosure index has been customized to the executive compensation disclosure by Swedish firms, in order to capture the variability of disclosure behavior among the firms in the sample. The index was validated by showing an inverse relation to bidask spread being a measure of information asymmetry (similarly to Laksmana 2008) (see Cieslak et al. 2016).

To test H4 I estimate a firm-fixed effects interaction regression model to capture how the slope of stock and accounting performance is affected by disclosure COMPLIANCE (3):

$$
\begin{aligned}
\operatorname{Ln}(\text { CEOPay })= & \beta 0+\beta 1 \text { COMPLIANCE }+\beta 2 \text { StockRe } t+\beta 3 R O A \\
& +\beta 4 \text { COMPLIANCE } * \text { Stock } \operatorname{Re}+\beta 5 \text { COMPLIANCE } * \text { ROA } * \\
& +\beta 6 \text { LogTotA }+\beta 7 \text { MktBook }+\beta 8 \text { OwnConc }+ \text { Year Dummies } \\
& + \text { Industry Dummies }+\varepsilon
\end{aligned}
$$




\section{Empirical results}

\subsection{Descriptive statistics}

\subsubsection{Ownership structure of Swedish listed firms}

Table 1 presents ownership data for the study sample of Swedish listed firms in years 2001-2013.

Family-controlled firms constitute around 70 per cent of the sample. The majority of family-controlled firms employ professional CEOs (around 80 per cent of familycontrolled firms versus 20 per cent of family-controlled firms with family CEOs). Dualclass shares are extremely common in family-controlled firms with family CEOs (76 per cent of these firms use dual-class shares), but less common for other types of firms. Around 53 per cent of family-controlled firms with professional CEOs use dual-class shares, and only around 18 per cent of non-family-controlled firms (the lowest usage of dual-class shares is among firms with institutional main owner, around 5.6 percent, whereas in firms with industrial main owner the percentage amounts to 31 percent, same as for firms with other owners, driven mostly by foundations-owned firms).

\subsubsection{Executive compensation, disclosure and firm characteristics}

Table 2 presents descriptive statistics of the study sample (see "Appendix" for definitions of variables). Continuous variables are winsorized at the 1st and 99th percentiles.

Panel A presents descriptive statistics of CEO pay on a yearly basis for the period 2001-2013. CEO pay increased from an average of 3 million SEK in 2001 to almost 7 million SEK in 2013. Nominally, pay increased by 229 per cent between 2001 and 2013. Given the inflation of 20.4 per cent in this period, the real growth of compensation amounted to 190 per cent. The structure of compensation in Sweden remains relatively stable. Fixed pay constitutes more than $53 \%$ of pay in all the years, which is relatively high compared to other countries (as reported by e.g. Fernandes et al. 2013). Bonus remains the main incentive compensation component in Sweden (ibid, Hallvarsson and Halvarsson 2011), and amounts to 20 per cent of pay on average. Compensation contracts in a number of firms oblige the CEO to invest parts of the bonus in company shares, in result bonus and share components are jointly presented. The relatively large pension component of compensation (around 22 per cent in the study period, on average), may be explained by high marginal taxes in Sweden.

Panel B presents executive compensation disclosure data from annual reports. The 7-item disclosure index increased almost three times, from an average of 1.59 in 2001 to 5.63 in 2013. At the same time, the standard deviation among firms decreased, meaning that there was less variability across firms in disclosure in 2013 than there was in 2001. 


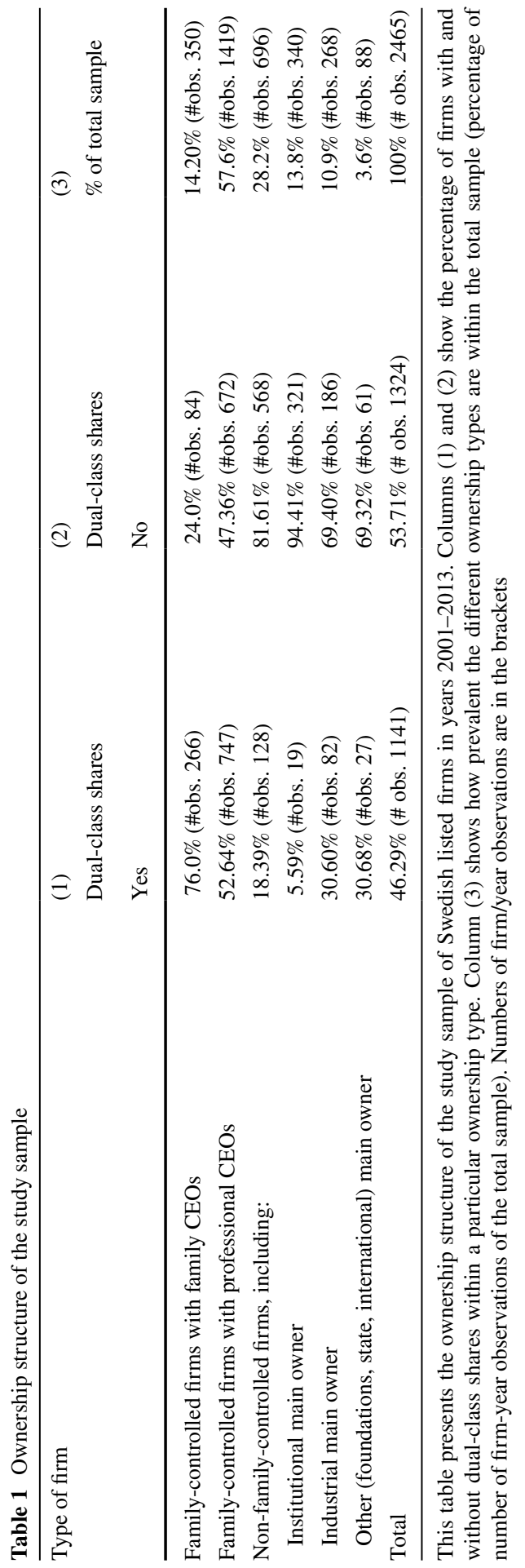


Table 2 Descriptive statistics for the study sample

\begin{tabular}{|c|c|c|c|c|c|c|c|c|c|c|c|c|c|}
\hline & 2001 & 2002 & 2003 & 2004 & 2005 & 2006 & 2007 & 2008 & 2009 & 2010 & 2011 & 2012 & 2013 \\
\hline Total pay (kSEK) & 2,973 & 3,542 & 3,834 & 4,629 & 5,278 & 5,615 & 5,708 & 5,704 & 5,772 & 6,350 & 6,442 & 6,622 & 6,808 \\
\hline Salary (kSEK) & N/a & $\mathrm{N} / \mathrm{a}$ & 2,560 & 2,799 & 2,953 & 3,227 & 3,301 & 3,150 & 3,478 & 3,439 & 3,604 & 3,841 & 4,083 \\
\hline$\%$ & N/a & $\mathrm{N} / \mathrm{a}$ & $61 \%$ & $56 \%$ & $53 \%$ & $55 \%$ & $54 \%$ & $55 \%$ & $59 \%$ & $54 \%$ & $56 \%$ & $58 \%$ & $60 \%$ \\
\hline Bonus \& shares (kSEK) & N/a & N/a & 588 & 1,000 & 1,226 & 1,350 & 1,345 & 1,146 & 1,002 & 1,337 & 1,311 & 1,164 & 1,121 \\
\hline$\%$ & N/a & $\mathrm{N} / \mathrm{a}$ & $14 \%$ & $20 \%$ & $22 \%$ & $23 \%$ & $22 \%$ & $20 \%$ & $17 \%$ & $21 \%$ & $20 \%$ & $18 \%$ & $16 \%$ \\
\hline Pension (kSEK) & N/a & N/a & 965 & 1,100 & 1,226 & 1,174 & 1,161 & 1,203 & 1,297 & 1,465 & 1,390 & 1,452 & 1,437 \\
\hline$\%$ & N/a & $\mathrm{N} / \mathrm{a}$ & $23 \%$ & $22 \%$ & $22 \%$ & $20 \%$ & $19 \%$ & $21 \%$ & $22 \%$ & $23 \%$ & $22 \%$ & $22 \%$ & $21 \%$ \\
\hline Other (kSEK) & $\mathrm{N} / \mathrm{a}$ & $\mathrm{N} / \mathrm{a}$ & 126 & 150 & 167 & 176 & 245 & 229 & 177 & 191 & 137 & 165 & 167 \\
\hline$\%$ & N/a & $\mathrm{N} / \mathrm{a}$ & $3 \%$ & $3 \%$ & $3 \%$ & $3 \%$ & $4 \%$ & $4 \%$ & $3 \%$ & $3 \%$ & $2 \%$ & $2 \%$ & $2 \%$ \\
\hline
\end{tabular}

Panel B: Disclosure index score of executive compensation

\begin{tabular}{llllllllllllll}
\hline & 2001 & 2002 & 2003 & 2004 & 2005 & 2006 & 2007 & 2008 & 2009 & 2010 & 2011 & 2012 & 2013 \\
\hline Average index score & 1.59 & 3.41 & 4.55 & 5.23 & 5.19 & 5.02 & 5.36 & 5.34 & 5.34 & 5.40 & 5.68 & 5.75 & 5.63 \\
Standard deviation & 1.74 & 2.08 & 1.91 & 1.64 & 1.84 & 2.09 & 1.76 & 1.87 & 1.72 & 1.70 & 1.46 & 1.36 & 1.47 \\
\hline
\end{tabular}

\begin{tabular}{|c|c|c|c|c|c|c|c|c|}
\hline & $\begin{array}{c}\text { (1) } \\
\text { All firms } \\
\text { (\#obs. 2,465) }\end{array}$ & $\begin{array}{c}(2) \\
\text { Family-controlled } \\
\text { firms with family } \\
\text { CEOs } \\
\text { (\#obs. 350) }\end{array}$ & $\begin{array}{c}(3) \\
\text { Family-controlled } \\
\text { firms with } \\
\text { professional } \\
\text { CEOs } \\
\text { (\#obs. 1,419) }\end{array}$ & $\begin{array}{c}(4) \\
\text { Non-family- } \\
\text { controlled firms } \\
\text { (\#obs.696) }\end{array}$ & $\begin{array}{c}\text { (5) } \\
\text { ANOVA } \\
\text { test of diff. }\end{array}$ & $\begin{array}{c}(6) \\
\text { Dual-class shares } \\
\text { YES } \\
\text { (\#obs. 1,141) }\end{array}$ & $\begin{array}{c}(7) \\
\text { Dual-class shares } \\
\text { NO } \\
(\# \text { obs. } 1,324)\end{array}$ & $\begin{array}{c}8) \\
T \text { test of diff. }\end{array}$ \\
\hline Dual-class & 0.46 & 0.76 & 0.53 & 0.18 & $214.19 * * *$ & N/A & N/A & N/A \\
\hline Wedge & 0.09 & 0.16 & 0.10 & 0.03 & $155.8 * * *$ & 0.19 & 0 & $0.19^{* * * *}$ \\
\hline Total assets(mSEK) & 11429 & 3505 & 8901 & 20567 & $39.23 * * *$ & 14601 & 8695 & $5906 * * * *$ \\
\hline ROA & 0.0001 & 0.03 & 0.002 & -0.02 & $7.94 * * *$ & 0.03 & -0.03 & $0.06^{* * * *}$ \\
\hline StockRet & 0.13 & 0.19 & 0.13 & 0.11 & $2.91 *$ & 0.14 & 0.13 & 0.01 \\
\hline MktBook & 3.10 & 3.20 & 3.01 & 3.20 & 0.81 & 2.73 & 3.41 & $-0.68 * * *$ \\
\hline OwnCEO & 0.07 & 0.44 & 0.008 & 0.01 & $3648^{* * * *}$ & 0.11 & 0.03 & $0.08^{* * * *}$ \\
\hline CEOComp (mSEK) & 5.18 & 2.32 & 5.40 & 6.18 & $71.47 * * *$ & 5.82 & 4.63 & $1.19^{* * * *}$ \\
\hline DISCINDEX & 4.79 & 4.16 & 4.83 & 5.00 & $19.05^{* * * *}$ & 4.85 & 4.73 & $0.12 *$ \\
\hline COMPLIANCE & 3.27 & 2.70 & 3.27 & 3.57 & $28.15 * * *$ & 3.28 & 3.27 & 0.01 \\
\hline
\end{tabular}

This table presents descriptive statistics (means) for a sample of 2,465 firm-year observations for Swedish listed firms in years 2001-2013. Variable definitions are provided in Appendix A. Continuous variables were winsorized at the $1^{\text {st }}$ and $99^{\text {th }}$ percentiles. Panel A presents the CEO pay and its components. Panel B presents disclosure average disclosure scores (maximum 7 points). Panel C presents performance and other firm characteristics for the total sample, as well as for subsamples of firms with different types of main owners and dual-class share status.

This table presents descriptive statistics (means) for a sample of 2465 firm-year observations for Swedish listed firms in years 2001-2013. Variable definitions are provided in "Appendix". Continuous variables were winsorized at the 1st and 99th percentiles. Panel A presents the CEO compensation and its components. Panel B presents disclosure average disclosure scores (maximum 7 points). Panel $\mathrm{C}$ presents performance and other firm characteristics for the total sample, as well as for subsamples of firms with different types of main owners and dual-class share status

Panel C presents firm characteristics for all firms (column 1) and in subsamples, based on identity of the main owner (columns 2-4) and usage of dual-class shares (columns 6-7). As mentioned in previous section, family-controlled firms with family CEOs have the highest usage of dual-class shares (76 per cent). Consequently, divergence between voting and cash flow rights of the main shareholder (a wedge), is the highest in these firms (16 per cent on average), compared with 10 per cent for family-controlled firms with professional CEOs, and 3 per cent for non-familycontrolled firms. Family-controlled firms with family CEOs are smaller in size than 
family-controlled firms with professional CEOs (3.5 bSEK of total assets vs. 8.9 bSEK) and non-family-controlled firms (20.6 bSEK). Family-controlled firms with family CEOs outperform the other firm types in accounting (stock) performance (an average ROA (stock return) for the study period of 3 (19) per cent versus 0 (13) per cent for family-controlled firms with professional CEOs and - 2 (11) per cent for non-family-controlled firms), although the difference is not statistically significant for stock returns. There are no significant differences in market-to-book ratio between the different firm types. Ownership of stock by the CEO averages at 44 per cent in family-controlled firms with family CEOs, compared with 0.8 per cent for family-controlled firms with professional CEOs and 1 per cent non-family-controlled firms. Compensation for family CEOs is the lowest $(2.32 \mathrm{mSEK}$ as compared with $5.4 \mathrm{mSEK}$ for professional CEOs in family-controlled firms and $6.18 \mathrm{mSEK}$ for CEOs in non-family-controlled firms). Family-controlled firms with family CEOs tend to disclose the least amount of information about executive compensation (an average disclosure index of 4.16 for the study period vs. 4.83 for family-controlled firms with professional CEOs and 5 for non-family-controlled firms).

In connection to the dual-class status (columns 6 and 7 of Panel $\mathrm{C}$ ) the average difference in wedge is 19 per cent in dual-class firms (and 0 per cent in single-class shares firms). Although the highest usage of dual-class shares is among the smallest family-controlled firms with family CEOs, on average dual-class firms are larger than non-dual-class firms (14.6 billion SEK vs. 8.7 billion SEK) (a number of large industrial and foundations-owned firms using dual-class shares drive the result). Dual-class firms report better accounting performance in the study period (3 per cent ROA vs. -3 per cent for non-dual-class firms), while the stock returns are almost identical for the two firm types and they are not statistically different (14 per cent vs. 13 per cent). Dual-class firms experience lower valuation (market-to-book ratio of 2.73 vs. 3.41 for non-dual class firms), which is in line with the findings by Cronqvist and Nilsson (2003) who attribute the valuation discount to the Type II agency conflict. CEO ownership in dual-class firms is significantly higher than in non-dual-class firms (11 per cent vs. 3 per cent), however CEO receive higher compensation in dual-class firms (5.82 $\mathrm{mSEK}$ vs. $4.6 \mathrm{mSEK})$, which is probably partly attributable to a larger size. Dual-class firms disclose slightly more information on executive compensation than non-dual class firms (the index of 4.85 vs. 4.73 ), but the difference is not significant.

Table 3 presents correlations between the study variables.

The highest correlation is between CEO pay and size of the company (positive). CEO pay is also significantly positively correlated with both accounting $(R O A)$ and stock performance (StockRet), dual-class status (DualClass), and the yearly disclosure compliance ranking (COMPLIANCE), as well as negatively correlated with the CEOFamily variable, stock ownership by the CEO (OwnCEO), and ownership by the largest owner (OwnConc). Among the independent variables, there is a considerably strong positive correlation between CEOFamily and OwnCEO variables, but no high VIFs (uncentered) above 5 exists for these variables in the models in which 


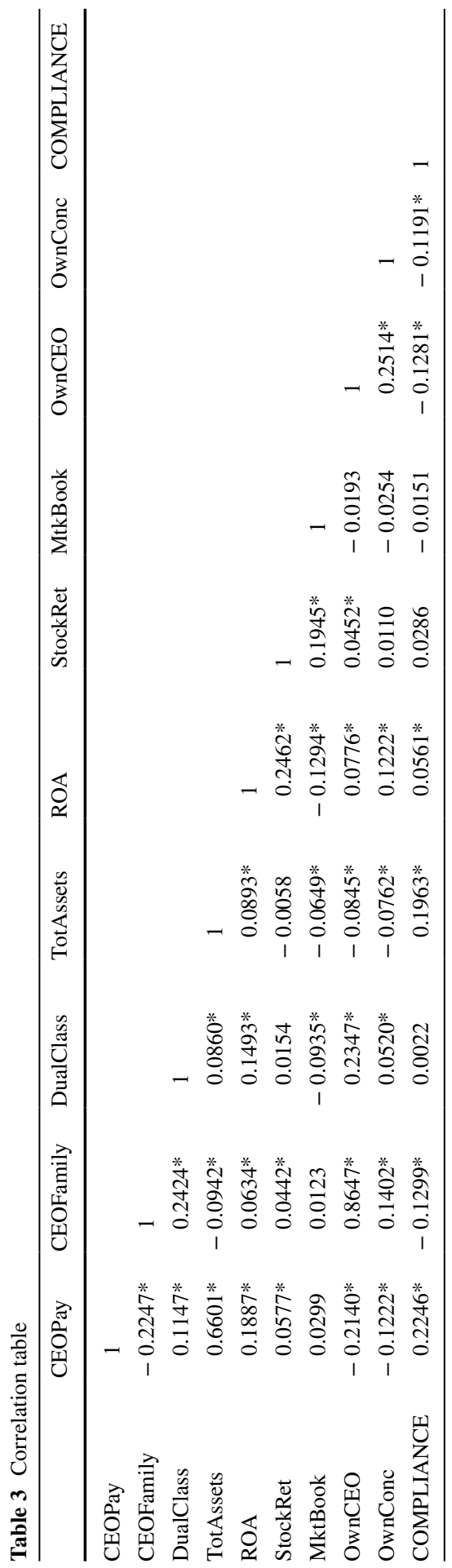


they both are used. ${ }^{12,13}$ Size of the firm is a variable with the highest VIFs in the estimated models, in few cases slightly exceeding $5 .^{14}$

\subsection{Multivariate analysis}

\subsubsection{Firm ownership and pay-performance sensitivity}

Table 4 presents results of firm-fixed effects regression models of CEO compensation depending on the owner identity.

As documented in Table 4 pay-performance sensitivity differs among different types of owners. While overall (model 1) there is a positive association between stock returns and CEO pay for all firms over the study period, these results are driven by firms other than family-controlled firms with family CEOs. In non-familycontrolled firms (model 2) there is a significant positive association between both stock and accounting performance and CEO pay and in family-controlled firms with professional CEOs pay is positively associated with stock performance. In contrast, in family-controlled firms with family CEOs neither of the coefficients of stock returns nor return on assets is statistically significant, implying that pay is detached from financial performance in these firms. An interaction model (5) documents that family CEOs decrease the sensitivity of CEO pay to stock performance (the coefficient on the interaction term CEOFamily_StockRet is negative and weakly statistically significant). I thus find partial support for $\mathrm{H} 1$ which states that pay-performance sensitivity is lower in family-controlled firms with family CEOs than in other family-controlled firms.

Interestingly, similarly to Croci et al. (2012) and Collin et al. (2014) I find that family-controlled firms with family CEOs in Sweden pay their CEOs less, ceteris paribus, than other firms (model 1). Compared with other countries, familycontrolled firms with family CEOs in Sweden do not seem to directly expropriate value from minority shareholders by paying excess pay to their CEOs. Collin et al. (2014) interpret this as a sign of strong governance. However, there seem to be another side of the coin to the governance at family-controlled firms with family CEOs. The weaker pay-performance sensitivity in family-controlled firms with family CEOs may imply less pressure for these CEOs and sheltering the CEO pay from consequences in face of poor financial performance, which is not necessarily in the interest of the minority shareholders.

Coefficients on control variables are mostly in line with what was previously documented by other studies. As expected, the coefficient of the size variable (LotTotA)

\footnotetext{
12 Dropping one of these variables does not affect direction or significance of coefficients for other variables.

13 There is a relatively high VIF (above 5) for OwnCEO variable in model 4 Table 4 for family-controlled firms with family CEOs. Exclusion of the $O w n C E O$ variable does not affect direction or significance of coefficients for other variables.

14 Models estimated after dropping the $\log T o t A$ variable yield essentially the same results, although exclusion of the variable negatively affects the power of the models.
} 


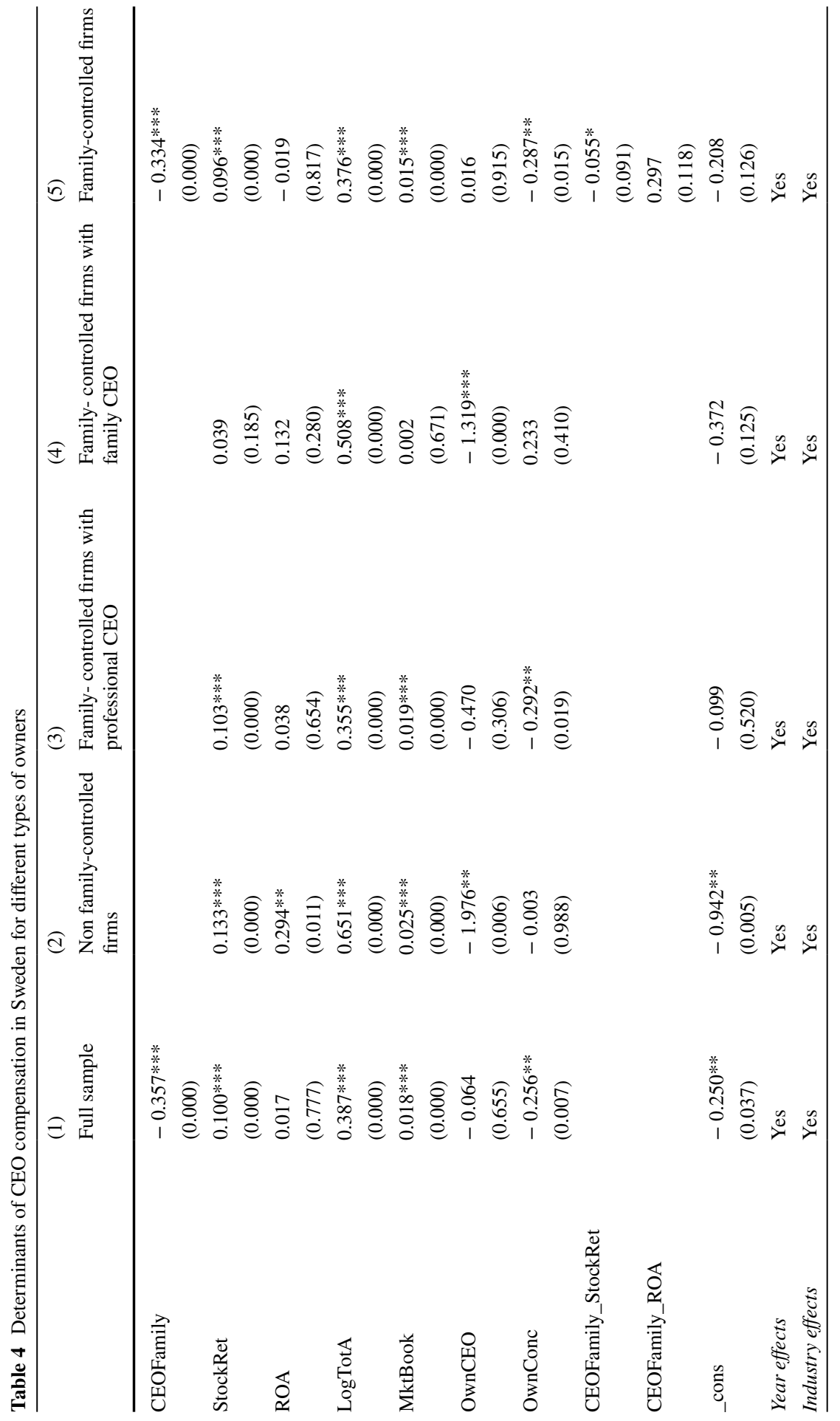




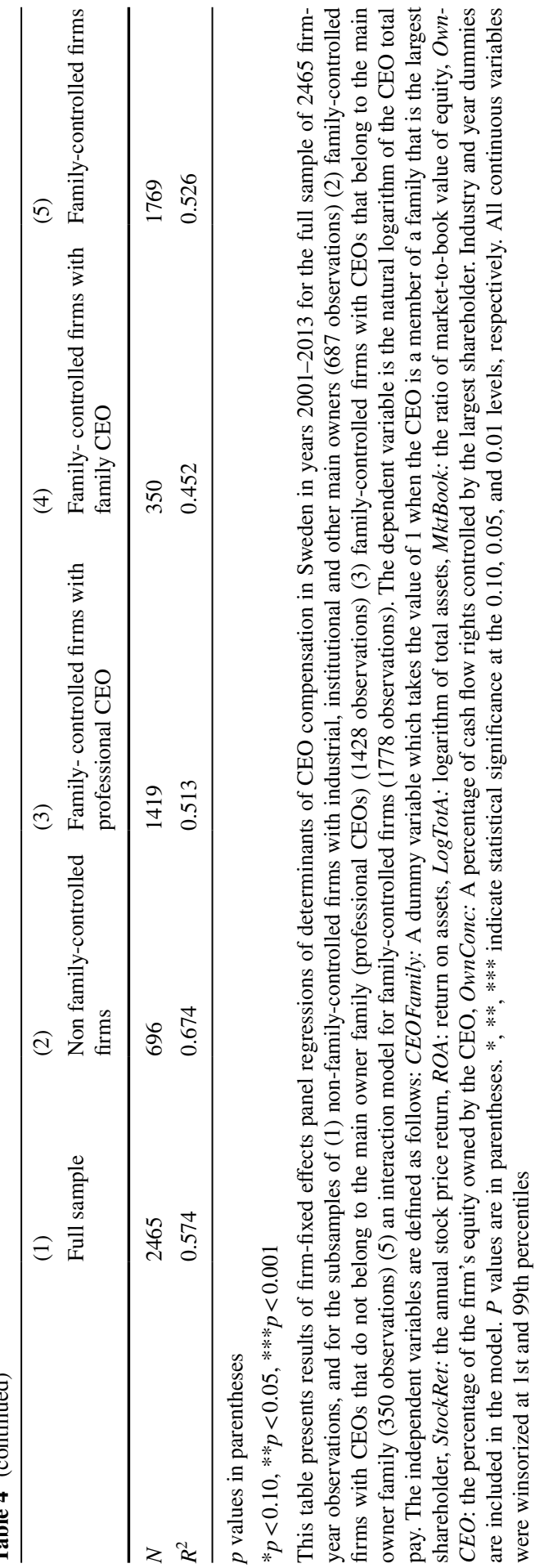


is significant and positive (Clarkson et al. 2011; Matolscy and Wright 2011; Gao and $\mathrm{Li}$ 2015), whereas coefficients of the OwnCEO and OwnConc variables are negative and significant, although not in all estimated models (Core et al. 1999; Clarkson et al. 2011; Gao and Li 2015; Collin et al. 2014). In contrast to previous research, the coefficient on MktBook control variable is either non-significant, or significant and positive (Clarkson et al. 2011 report a negative association between growth opportunities and pay).

While practices in family-controlled firms with family CEOs may be driven by family ties, the conjecture of this study is that in other types of firms the control preference, substantiated by a usage of dual-class shares, is an important driver of CEO pay. Table 5 presents results of firm-fixed effects regression models of CEO pay depending on the firm's dual-class status.

In contrast to what was found in other countries (Masulis et al. 2009; AmoakoAdu et al. 2011) dual-class status does not seem to directly increase the CEO pay level in Sweden. The coefficient on DualClass variable is insignificant in all models, so I do not find evidence for direct expropriation of value by the controlling shareholder using excess pay to the CEO, supposedly to gain CEO's loyalty. Model (3) reveals that in single-class firms there is a significant positive association between both stock and accounting performance and CEO pay. In dual-class firms (model 4) there is a significant positive association only between stock returns and CEO pay, but not between accounting performance and CEO pay. Coefficient for ROA variable is negative, implying 'reward for failure', and weakly statistically significant. An interaction model (5) documents that dual-class status decrease the sensitivity of CEO pay to accounting performance (the coefficient on the interaction term DualClass_ROA is negative and statistically significant). I thus find partial support for $\mathrm{H} 2$ which states that pay-performance sensitivity in dual-class firms is weaker than in single-class firms, as these firms try to align CEO's interest with the will of the controlling shareholder, rather than with financial performance.

\subsubsection{Executive compensation regulations and pay-performance sensitivity}

Next in analysis I investigate pay-performance sensitivity in Sweden for different time periods to capture a potential impact of executive compensation regulations on the focal relationship between pay and performance. Results are presented in Table 6 (models 1-2).

While previous research from Anglo-Saxon countries documents increased payperformance sensitivity in highly regulated environments (Vafeas and Afxentiou 1998; Clarkson et al. 2011; Ferri and Maber 2013), results from Table 6 imply that in the latest years, when all the regulations were in place, pay-performance sensitivity decreased. I thus do not find support for $\mathrm{H} 3$, which states that pay-performance sensitivity is the highest in the period of 2010-2013 following implementation of the EC recommendations. Neither StockRet nor ROA coefficients are statistically significant in the latest period. Pay seems to be detached from performance in the latest period. This result is in contrast with the stipulated goal of the European Commission, 'to ensure pay for performance' (European Commission 2009), which is puzzling. 
Table 5 CEO compensation in Sweden and dual-class shares status

\begin{tabular}{|c|c|c|c|c|c|}
\hline & (1) & (2) & (3) & (4) & (5) \\
\hline & Full sample & Full sample & Non-dual-class firms & Dual-class firms & Full sample \\
\hline \multirow[t]{2}{*}{ DualClass } & -0.049 & -0.029 & & & -0.052 \\
\hline & $(0.235)$ & $(0.458)$ & & & $(0.193)$ \\
\hline \multirow[t]{2}{*}{ StockRet } & & $0.099 * * *$ & $0.089 * * *$ & $0.129 * * *$ & $0.092 * * *$ \\
\hline & & $(0.000)$ & $(0.000)$ & $(0.000)$ & $(0.000)$ \\
\hline \multirow[t]{2}{*}{ ROA } & & 0.011 & $0.160^{* *}$ & $-0.183^{*}$ & $0.117^{*}$ \\
\hline & & $(0.852)$ & $(0.038)$ & $(0.073)$ & $(0.081)$ \\
\hline \multirow[t]{2}{*}{ LogTotA } & & $0.398 * * *$ & $0.429 * * *$ & $0.269 * * *$ & $0.406^{* * *}$ \\
\hline & & $(0.000)$ & $(0.000)$ & $(0.000)$ & $(0.000)$ \\
\hline \multirow[t]{2}{*}{ MktBook } & & $0.018 * * *$ & $0.020 * * *$ & $0.016^{* * *}$ & $0.019^{* * *}$ \\
\hline & & $(0.000)$ & $(0.000)$ & $(0.000)$ & $(0.000)$ \\
\hline \multirow[t]{2}{*}{ OwnCEO } & & $-0.650 * * *$ & $-2.187 * * *$ & $-0.378 * * *$ & $-0.635^{* * *}$ \\
\hline & & $(0.000)$ & $(0.000)$ & $(0.000)$ & $(0.000)$ \\
\hline \multirow[t]{2}{*}{ OwnConc } & & $-0.208^{* *}$ & -0.033 & $-0.398 * *$ & $-0.210^{* *}$ \\
\hline & & $(0.031)$ & $(0.821)$ & $(0.008)$ & $(0.029)$ \\
\hline \multirow[t]{2}{*}{ DualClass_HistRet } & & & & & 0.028 \\
\hline & & & & & $(0.311)$ \\
\hline \multirow[t]{2}{*}{ DualClass_ROA } & & & & & $-0.369 * * *$ \\
\hline & & & & & $(0.001)$ \\
\hline \multirow[t]{2}{*}{ _cons } & $1.010 * * *$ & $-0.281 * *$ & $-0.272 *$ & 0.112 & $-0.301 * *$ \\
\hline & $(0.000)$ & $(0.021)$ & $(0.097)$ & $(0.536)$ & $(0.013)$ \\
\hline Year effects & Yes & Yes & Yes & Yes & Yes \\
\hline Industry effects & Yes & Yes & Yes & Yes & Yes \\
\hline$N$ & 2465 & 2465 & 1324 & 1141 & 2465 \\
\hline$R^{2}$ & 0.082 & 0.572 & 0.575 & 0.558 & 0.569 \\
\hline
\end{tabular}

$p$ values in parentheses

$* p<0.10, * * p<0.05, * * * p<0.001$

This table presents results of firm-fixed effect regressions for a full sample of 2465 firm-year observations for years 2001-2013 and for subsamples of non-dual-class firms (1324 observations, model 3) and dual-class firms (1141 observations, model 4). The dependent variable is the natural logarithm of the CEO compensation. The independent variables are defined as follows: Dual-class: A dummy variable which takes the value of 1 when a firm uses dual-class shares; StockRet: the annual stock price return, ROA: return on assets, LogTotA: logarithm of total assets, MktBook: the ratio of market to book value of equity, OwnCEO: the percentage of the firm's equity owned by the CEO. OwnConc: A percentage of cash flow rights controlled by the largest shareholder. Industry and year dummies are included in the model. $P$ values are in parentheses. $*, * *, * * *$ indicate statistical significance at the $0.10,0.05$, and 0.01 levels, respectively. All continuous variables were winsorized at 1 st and 99 th percentiles

Several explanations of the results could be articulated. Previous evidence of increased pay-performance sensitivity in a more regulated environment come from the Anglo-Saxon countries, where Type I agency conflict is most pervasive. Variable pay historically comprises a larger part of compensation in these countries (Fernandes et al. 2013). Pay for failure and excessive compensation disconnected 
from performance were limited by the regulations, as documented in these studies. However, limiting variable pay is a double -edged sword. Two of the four guidelines from the 2009 Recommendation: (1) ensuring 'a balance' between variable and fixed pay and clear performance criteria, and (2) deferment of variable pay ${ }^{15}$ could lead to more fixed pay. Where variable pay was a much smaller part of total compensation (as applies to the Swedish case), slashing this component of pay could result in weaker pay-performance sensitivity.

National institutional settings could also be considered in explaining the results (Van Essen et al. 2012; Wiseman et al. 2012). Sweden is an egalitarian society, with management focus on collectivism rather than admiration of star performers (Isaksson 2008; Holmberg and Åkerblom 2012). More openness about compensation levels through higher overall disclosure of executive compensation could lead to homogenizing of pay among CEOs.

Table 6 (column 3) also presents results concerning disclosure as a channel through which pay-performance sensitivity could be influenced. Although executive compensation disclosure grew significantly in the study period, firms differed in their regulatory compliance levels. While previous research suggests that disclosure can work as a control mechanism from external stakeholders and incentivize firm to reassess their compensation packages and align pay with performance (Clarkson et al. 2011; De Franco et al. 2013) the results from the study do not seem to support these conjectures. Coefficients on interaction variables COMPLIANCE_StockRet and COMPLIANCE_ROA are not significant and I do not find support for $\mathrm{H} 4$ which states that disclosure of executive compensation positively affects pay-performance sensitivity. One interesting finding is that in the Swedish setting the level of compliance with disclosure rules positively affects the level of compensation. While in an Anglo-Saxon setting previous research finds that disclosure defects are associated with CEO overpayment (Robinson et al. 2011; Laksmana et al. 2012), in an egalitarian Swedish setting higher compliance seems to legitimize higher CEO pay.

\section{Discussion and conclusions}

In this paper, I study CEO pay-performance sensitivity in Swedish listed firms in a changing regulatory environment. With a high prevalence of family-controlled firms, strong representation of major shareholders on boards and popularity of dual-class shares, the Swedish context is highly representative for Type II agency conflicts. Type II agency conflicts between controlling and non-controlling shareholders are potentially important for many European companies as evidenced by several calls for more research about how such conflicts affect compensation practices in firms (Courteau et al. 2017; Barontini et al. 2017). Previous European evidence focuses on level of pay or pay structure (Croci et al. 2012; Barontini and Bozzi 2011; Collin et al. 2014; Barontini et al. 2017). I complement this research

15 The other two being limits in severance pay and clawback provisions. 
Table 6 CEO compensation in Sweden in different time periods and for different compliance levels

\begin{tabular}{|c|c|c|c|}
\hline & $\begin{array}{l}\text { (1) } \\
\text { 2001-2009 }\end{array}$ & $\begin{array}{l}\text { (2) } \\
2010-2013\end{array}$ & (3) \\
\hline CEOFamily & $\begin{array}{l}-0.491 \text { *** } \\
(0.000)\end{array}$ & $\begin{array}{l}-0.575^{* * *} \\
(0.000)\end{array}$ & $\begin{array}{l}-0.264^{*} \\
(0.082)\end{array}$ \\
\hline COMPLIANCE & & & $\begin{array}{l}0.047 * * * \\
(0.000)\end{array}$ \\
\hline DualClass & $\begin{array}{l}0.039 \\
(0.420)\end{array}$ & $\begin{array}{l}0.090 \\
(0.111)\end{array}$ & $\begin{array}{l}0.065 \\
(0.166)\end{array}$ \\
\hline StockRet & $\begin{array}{l}0.116 \text { *** } \\
(0.000)\end{array}$ & $\begin{array}{l}-0.031 \\
(0.522)\end{array}$ & $\begin{array}{l}0.116^{* *} \\
(0.008)\end{array}$ \\
\hline ROA & $\begin{array}{l}-0.080 \\
(0.390)\end{array}$ & $\begin{array}{l}0.123 \\
(0.375)\end{array}$ & $\begin{array}{l}-0.143 \\
(0.350)\end{array}$ \\
\hline $\log$ TotA & $\begin{array}{l}0.695 * * * \\
(0.000)\end{array}$ & $\begin{array}{l}0.673 * * * \\
(0.000)\end{array}$ & $\begin{array}{l}0.669 * * * \\
(0.000)\end{array}$ \\
\hline MktBook & $\begin{array}{l}0.028 * * * \\
(0.000)\end{array}$ & $\begin{array}{l}0.047 * * * \\
(0.000)\end{array}$ & $\begin{array}{l}0.031 * * * \\
(0.000)\end{array}$ \\
\hline OwnConc & $\begin{array}{l}-0.615^{* * * *} \\
(0.000)\end{array}$ & $\begin{array}{l}-0.515^{* *} \\
(0.011)\end{array}$ & $\begin{array}{l}-0.571 * \\
(0.088)\end{array}$ \\
\hline COMPLIANCE*StockRet & & & $\begin{array}{l}-0.008 \\
(0.457)\end{array}$ \\
\hline COMPLIANCE*ROA & & & $\begin{array}{l}0.033 \\
(0.380)\end{array}$ \\
\hline _cons & $\begin{array}{l}-1.064 * * * \\
(0.000)\end{array}$ & $\begin{array}{l}-0.750 * * * \\
(0.000)\end{array}$ & $\begin{array}{l}-1.263^{* * *} \\
(0.000)\end{array}$ \\
\hline Year effects & Yes & Yes & Yes \\
\hline Industry effects & Yes & Yes & Yes \\
\hline $\mathrm{N}$ & 1771 & 694 & 2465 \\
\hline $\mathrm{R} 2$ & 0.645 & 0.680 & 0.661 \\
\hline
\end{tabular}

$p$ values in parentheses

$* p<0.10, * * p<0.05, * * * p<0.001$

This table presents results of OLS regressions for subsamples of firms in different time periods (models 1 and 2) and firm-fixed effect regressions for a full sample of 2465 firm-year observations for years 20012013 (model 3). The dependent variable is the natural logarithm of the CEO total pay. The independent variables are defined as follows: StockRet: the annual stock price return, ROA: return on assets, Dual-class: A dummy variable which takes the value of 1 when a firm uses dual-class shares, CEOFamily: A dummy variable which takes the value of 1 when the CEO is a family member of the main shareholder, LogTotA: logarithm of total assets, MktBook: the ratio of market to book value of equity, OwnConc: A percentage of cash flow rights controlled by the largest shareholder; Compliance: A variable which divides the observations on a yearly basis in seven quintiles based on the disclosure score. Industry- and year- dummies are included in the model, and standard errors are clustered at the firm level (models 1 and 2 ). $P$ values are in parentheses. $*, * *, * * *$ indicate statistical significance at the $0.10,0.05$, and 0.01 levels, respectively. All continuous variables were winsorized at 1 st and 99 th percentiles 
by studying pay-performance sensitivity (Ke et al. 1999; Gao and Li 2015) in firms with Type II agency conflicts.

The study results suggest that pay-performance sensitivity in family-controlled firms with family CEOs is significantly lower than in other types of firms. Whereas CEO pay is driven by both stock and accounting performance in nonfamily-controlled firms, and by stock performance in family-controlled firms with professional CEOs, in family-controlled firms with family CEOs CEO pay is detached from stock and accounting performance. I also find some evidence that dual-class shares firms have significantly lower sensitivity of pay to accounting performance than non-dual-class firms. These results yield the following conclusions: Whereas 'management power' theory is used in research in the AngloSaxon context to explain CEO compensation (Bebchuk and Fried 2003; Morse et al. 2011; Gao and Li 2015), in Europe the 'controlling shareholders' power' theory could be more relevant. I suggest that family ties and the power preference of the main shareholder who uses compensation to align CEO's interest with his/her will rather than with financial performance are responsible for lower payperformance sensitivity. The 'controlling shareholders' power' effect seems to be especially pervasive in family firms.

One potential limitation of the study is that performance is measured in financial terms, i.e. as stock returns or return on assets. However, other types of performance, e.g. corporate social responsibility (CSR) performance could be taken into consideration in different types of firms when they set CEO compensation. In this case, weaker pay-performance sensitivity may indicate different organizational goals rather than non-optimal firm practices, when considered from the point of view of minority shareholders.

The study also develops previous research concerning the impact of executive compensation regulations on pay-setting process in firms (Vafeas and Afxentiou 1998; Zhou and Swan 2006; Ferri and Maber 2013; Clarkson et al. 2011). Unlike in the Anglo-Saxon context, there is no clear evidence that the stipulated goal of the European Commission, 'to ensure pay for performance' (European Commission 2009) has been reached in Sweden. Rather, the pay-performance link disappeared in the latest time period 2010-2013. Notably, the new caveats contained in EC recommendations for variable pay may function as a double- edged sword that limits pay for performance rather than enhancing it. The results of the study draw attention to the importance of national settings in studying contracting practices (Van Essen et al. 2012; Wiseman et al. 2012). In the Swedish egalitarian environment where star performers in firms are rarely glorified (Isaksson 2008; Holmberg and Åkerblom 2012), more openness about compensation to the CEOs has possibly led to equalizing of pay among the Swedish CEOs and the detachment of pay from performance.

At the same time, it must be noted that one important outcome of the regulations has been a significant shift up in the total level of CEO pay. Pay grew almost twice in real terms during the time studied. In the previous decade, executive compensation 
has become a European issue and more openness has allowed firms to engage in benchmarking at national and international levels. In a relatively small labor market such as Sweden, this appears to increase market competition pressures, thus inducing higher pay. While Swedish CEOs belong to the least paid in developed economies (see e.g. Fernandes et al. 2013), the higher pay levels have received business media attention in the last years. Striking in the articles from the business press is the tendency of boards to defend pay rises in relation to 'matching the market' rather than to extraordinary CEO performance. ${ }^{16}$ Murphy (2013) and Leuz and Wysocki (2015) warn about externalities of regulations in terms of unintended consequences. One clear trend for the higher overall disclosure regime in Sweden is the higher overall CEO pay. The 'keeping up with the Jones' theory (see Zhou and Swan 2006) may indeed have materialized in Sweden.

Hence, the study also raises a voice in a debate concerning the efficacy of regulations. More research is certainly warranted to judge if standardization endeavors are in fact needed, particularly in the context of different institutional settings. There are various potential difficulties linked with standardizing policies in Europe, given its mosaic of different environments.

Acknowledgements I thank the Editors of this special issue and two anonymous reviewers for their valuable comments. Furthermore, I thank the participants of the Nordic Accounting Conference 2016 (Copenhagen), the 37th Annual Congress of the European Accounting Association (Tallin), and the 21st Global Finance Conference (Dubai) for useful comments on earlier versions of the paper. I thank my colleagues at the Department of Business Studies for useful insights, and especially Mattias Hamberg (the Department of Business Studies, Uppsala University, and the Department of Accounting, Auditing and Law at the Norwegian School of Economics and Business Administration (NHH)) for valuable comments and for providing access to compilation of ownership and financial data. I also thank Shruti Kashyap, doctoral student at the department, for help with language editing. This research has been partly funded by stipend from Jan Wallander and Tom Hedelius Foundation, which I gratefully acknowledge. Any errors are of mine.

Open Access This article is distributed under the terms of the Creative Commons Attribution 4.0 International License (http://creativecommons.org/licenses/by/4.0/), which permits unrestricted use, distribution, and reproduction in any medium, provided you give appropriate credit to the original author(s) and the source, provide a link to the Creative Commons license, and indicate if changes were made.

\section{Appendix}

See Table 7.

\footnotetext{
${ }^{16}$ For articles in the Swedish press see, for example: 'Försvarar jättelönen', Dagens Industri, 26 March, 2014, or 'Lönelyft för Börje Ekholm', Dagens Industri, 26 March, 2014 accessed on www.di.se.
} 
Table 7 Variable definitions

Ln(CEOPay) The natural logarithm of CEO total pay including salary, bonus, share grants, pensions, and other (e.g. relocation allowance, firm car, additional insurance)

CEOFamily A dummy variable which takes the value of 1 when the CEO is a family member of the main shareholder

StockRet The annual stock price return

$R O A \quad$ The annual return on assets

LogTotA The natural logarithm of total assets

MktBook The ratio of market-to-book value: the end of year market value of equity divided by the end of year book value of equity

OwnCEO The percentage of the firm's equity owned by the CEO

OwnConc A percentage of cash flow rights controlled by the largest shareholder

Dualclass A dummy variable which takes the value of 1 for firms that use dual-class shares

COMPLIANCE A variable which divides the observations in seven quintiles on a yearly basis based on the disclosure score (DISCINDEX)

DISCINDEX A disclosure index developed by Cieslak et al. (2016) which one point to the following disclosure components

INDX_1: 1 point, if information on the total compensation is decomposed into compensation components

INDX_2: 1 point, if it is clearly noted in the text that (1) the CEO receives no variable compensation, or (2) it is disclosed that a variable compensation exists and at least two of the following issues are disclosed: (a) the extent to which bonus targets were met, (b) the maximum achievable level of bonus, and (c) information on how bonus targets are evaluated

INDX_3: 1 point, if information on CEO retirement conditions is disclosed

INDX_4: 1 point, if information on other top executives' retirement conditions is disclosed

INDX_5: 1 point, if information on how the contract with the CEO can be terminated is disclosed. This includes, for example, if there are differences between a voluntary and a forced contract termination

INDX_6: 1 point, if information on severance packages is disclosed

INDX_7: 1 point, if information on other top executives is disclosed by either (1) decomposing the total amount of compensation into more than one component, or (2) discussing how other top executives are compensated

\section{References}

Amoako-Adu, B., Baulkaran, V., \& Smith, B. F. (2011). Executive compensation in firms with concentrated control: The impact of dual class structure and family management. Journal of Corporate Finance, 17, 1580-1594.

Barontini, R., \& Bozzi, S. (2011). Board compensation and ownership structure: Empirical evidence for Italian listed firms. Journal of Management and Governance, 15, 59-89.

Barontini, R., Bozzi, S., \& Ferrarini, G. (2017). Executive remuneration standards and the 'conformity gap' at controlled corporations. Journal of Management and Governance, 21, 573-597.

Barak, R., Cohen, S., \& Lauterbach, B. (2015). The effect of CEO pay on firm valuation in closely held firms. International Corporate Governance. https://doi.org/10.1108/S1569-3732(2011)00000 14004.

Bebchuk, L. A., \& Fried, J. M. (2003). Executive compensation as an agency problem. Journal of Economic Perspectives, 17, 71-92. 
Bebchuk, L. A., \& Fried, J. M. (2004). Pay without performance: The unfulfilled promise of executive compensation. Cambridge: Harvard University Press.

Bebchuk, L. A., Kraakman, R., \& Triantis, G. (2000). Stock pyramids, cross-ownership, and dual-class equity: The creation of agency costs of separating control from cash flow rights. In R. Morck (Ed.), Concentrated corporate ownership. Chicago, IL: University of Chicago Press.

Carlsson, R. (2007). Swedish corporate governance and value creation: Owners still in the driver's seat. Corporate Governance, 15(6), 1038-1055.

Cieslak, K., Hamberg, M., \& Vural, D. (2016). Executive compensation disclosure incentives: The case of Sweden, Working Paper, Uppsala University.

Clarkson, P. M., Walker, J., \& Nicholls, S. (2011). Disclosure, shareholder oversight and the pay-performance link. Journal of Contemporary Accounting and Economics, 7(2), 47-64.

Claessens, S., Djankov, S., Fan, J. P. H., \& Lang, L. H. P. (2002). Disentangling the incentive and entrenchment effects of large shareholdings. Journal of Finance, 57, 2741-2771.

Cohen, S., \& Lauterbach, B. (2008). Differences in pay between owner and non-owner CEOs: Evidence from Israel. Journal of Multinational Financial Management, 18, 4-15.

Collin, S. O. Y., Gustafsson, L., Petersson, E., \& Smith, E. (2014). Options are a CEO's best friend: Executive compensation in Swedish listed corporations. IUP Journal of Corporate Governance, $13(3), 40-71$.

Conyon, M. J. (2006). Executive compensation and incentives. Academy of Management Perspectives, $20(1), 25-44$.

Core, J. E., Wayne, G., \& Larcker, D., F. (2001) Executive equity compensation and incentives: A survey, Working paper, Wharton School.

Core, J., Holthausen, R., \& Larcker, D. (1999). Corporate governance, chief executive officer compensation, and firm performance. Journal of Financial Economics, 51, 371-406.

Courteau, L., di Pietra, R., Giudici, P., \& Melis, A. (2017). The role and effect of controlling shareholders in corporate governance. Journal of Management and Governance, 21, 561-572.

Croci, E., Gonenc, H., \& Ozkan, N. (2012). CEO compensation, family control, and institutional investors in Continental Europe. Journal of Banking and Finance, 36, 3318-3335.

Cronqvist, H., \& Nilsson, M. (2003). Agency costs of controlling minority shareholders. The Journal of Financial and Quantitative Analysis, 38(4), 695-719.

De Franco, G., Hope, O.-K., \& Larocque, S. (2013). The effect of disclosure on the pay-performance relation. Journal of Accounting and Public Policy, 32(5), 319-341.

De Cesari, A., Gonenc, H., \& Ozkan, N. (2016). The effects of corporate acquisitions on CEO compensation and CEO turnover of family-controlled firms. Journal of Corporate Finance, 38, 294-317.

Devers, C. E., McNamara, G., Wiseman, R. M., \& Arrfelt, M. (2008). Moving closer to the action: Examining compensation design effects on firm risk. Organization Science, 19(4), 548-566.

Enriques, L. (2015). Related party transactions: Policy options and real-world challenges (with a critique of the European Commission proposal). European Business Organization Law Review, 16(1), 1-37.

Elsaid, E., \& Davidson, W. N. (2009). What happens to CEO compensation following turnover and succession? Quarterly Review of Economics and Finance, 49, 424-447.

Faccio, M., \& Lang, L. H. (2002). The ultimate ownership of Western European corporations. Journal of Financial Economics, 65, 365-395.

Faulkender, M., Kadyrzhanova, D., Prabhala, N., \& Senbet, L. (2010). Executive compensation: An overview of research on corporate practices and proposed reforms. Journal of Applied Corporate Finance, 22(1), 107-118.

Fernandes, N., Ferreira, M., Matos, P., \& Murphy, K. (2013). Are U.S. CEOs paid more? New international evidence. Review of Financial Studies, 26(2), 323-367.

Ferri, F., \& Maber, D. A. (2013). Say on pay votes and CEO compensation: Evidence from the UK. Review of Finance, 17(2), 527-563.

Fristedt, D., \& Sundqvist, S. I, (2001-2009). Ägarna och Makten i Sveriges Börsföretag 2001-2009, [Ownership and Power in Swedish Listed Corporations], SIS Ägarservice AB, Stockholm.

Gao, H., \& Li, K. (2015). A comparison of CEO pay-performance sensitivity in privately-held and public firms. Journal of Corporate Finance, 35, 370-388.

Gomez-Mejia, L. R., Larraza, M., \& Makri, M. (2003). The determinants of CEO compensation in family-controlled public corporations. Academy of Management Journal, 46, 226-237.

Hallvarsson \& Halvarsson (2011). Hallvarsson \& Halvarssons rapport om VD-ersättningar 2010, http:// www.ersattningsakademien.se/hallvarsson-halvarssons-rapport-om-vd-ersattningar-2010/. 
Holmberg, I., \& Åkerblom, S. (2012). "Pirmus Inter Pares": Leadership and culture in Sweden. In J. S. Chhokar, F. C. Brodbeck, \& R. J. House (Eds.), Culture and leadership across the world: The GLOBE book of in-depth studies of 25 societies. New York: Taylor \& Francis.

Institutional Shareholder Services (2007) Proportionality between ownership and control in EU listed firms, External study commissioned by the European Commission, www.ecgi.org/osov/docum ents/final_report_en.pdf.

Isaksson, P. (2008). Leading companies in a global age-Managing the Swedish way. Vinnova: Stockholm.

Jensen, M. C., \& Meckling, W. (1976). Theory of the firm: Managerial behavior, agency costs, and ownership structure. Journal of Financial Economics, 3(4), 305-360.

Jensen, M. C., \& Murphy, K. J. (1990). Performance pay and top-management incentives. The Journal of Political Economy, 98(2), 225-264.

Jensen, M. C., \& Murphy, K. J. (2010). CEO incentives: It's not how much you pay, but how. Journal of Applied Corporate Finance, 22(1), 64-76.

Ke, B., Petroni, K., \& Safieddine, A. (1999). Ownership concentration and sensitivity of executive pay to accounting performance measures: Evidence from publicly and privately-held insurance firms. Journal of Accounting and Economics, 28(2), 185-209.

La Porta, R., Lopez-de-Silanes, F., \& Shleifer, A. (1999). Corporate ownership around the world. The Journal of Finance, 54(2), 471-517.

La Porta, R., Lopez-de-Silanes, F., Shleifer, A., \& Vishny, R. W. (2002). Investor protection and corporate valuation. Journal of Finance, 57, 1147-1170.

Laksmana, I. (2008). Corporate board governance and voluntary disclosure of executive compensation practices. Contemporary Accounting Research, 25(4), 1147-1182.

Laksmana, I., Tietz, W., \& Yang, Y.-W. (2012). Compensation discussion and analysis (CD\&A): Readability and management obfuscation. Journal of Accounting Public Policy, 31, 185-203.

Leuz, C., \& Wysocki, P. D. (2015). The economics of disclosure and financial reporting regulation: Evidence and suggestions for future research, Working paper, University of Chicago.

Masulis, R., Wang, C., \& Xie, F. (2009). Agency problems at dual class companies. Journal of Finance, 64, 1697-1727.

Matolscy, Z., \& Wright, A. (2011). CEO compensation structure and firm performance. Accounting and Finance, 51(3), 745-763.

Melis, A., Gaia, S., \& Carta, S. (2015). Directors' remuneration: A comparison of Italian and UK non-financial listed firms' disclosure. The British Accounting Review, 47, 66-84.

Morse, A., Nanda, V., \& Seru, A. (2011). Are incentive contracts rigged by powerful CEOs? Journal of Finance, 56, 1779-1821.

Murphy, K. J. (2013). The politics of pay: A legislative history of executive compensation. In S. T. Randall \& J. G. Hill (Eds.), Research handbook on executive pay. Cheltenham: Edward Elgar Publishers.

Muslu, V. (2010). Executive directors, pay disclosures and incentive compensation in large European firms. Journal of Accounting, Auditing, and Finance, 25, 569-603.

Robinson, J. R., Xue, Y., \& Yu, Y. (2011). Determinants of disclosure non-compliance and the effect of the SEC review: Evidence from 2006 mandate compensation disclosure regulations. The Accounting Review, 86, 1415-1444.

Shleifer, A., \& Vishny, R. W. (1986). Large shareholders and corporate control. Journal of Political Economics, 94, 461-488.

Shleifer, A., \& Vishny, R. W. (1997). A survey of corporate governance. Journal of Finance, 52, 737-783.

Sundqvist, S. I. (2010-2013), Ägarna och Makten i Sveriges Börsföretag 2010-2013, [Ownership and Power in Swedish Listed Corporations], SIS Ägarservice AB, Stockholm.

Tosi, H., Werner, S., Katz, J., \& Gomez-Mejia, L. (2000). How much does performance matter? A metaanalysis of CEO pay studies. Journal of Management, 26(2), 301-339.

Vafeas, N., \& Afxentiou, Z. (1998). The association between the SEC's 1992 compensation disclosure rule and executive compensation policy changes. Journal of Accounting and Public Policy, 17, 27-54.

Van Essen, M., Heugens, P., Ottan, J., \& van Oosterhout, J. (2012). An institution-based view of executive compensation: A multilevel meta-analytic test. Journal of International Business Studies, 43, 396-423. 
Wiseman, R., Cuevas-Rodriguez, G., \& Gomez-Mejia, L. (2012). Towards a social theory of agency. Journal of Management Studies, 49, 202-222.

Zhou, X., \& Swan, P. L. (2006). Does executive compensation disclosure alter pay at the expense of incentives? http://dx.doi.org/10.2139/ssrn.910865.

\subsection{Laws and regulations}

2004/913/EC. Commission Recommendation of 14 December 2004 fostering an appropriate regime for the remuneration of directors of listed firms, http://eur-lex.europa.eu/LexUriServ/LexUriServ.do?uri $=$ OJ:L:2004:385:0055:0059:EN:PDF, 23.06.2014.

2005/162/EC. Commission Recommendation of 15 February 2005 on the role of non-executive or supervisory directors of listed companies and on the committees of the (supervisory) board.

2009/385/EC. Commission Recommendation of 30 April 2009 complementing Recommendations 2004/913/EC and 2005/162/EC as regards the regime for the remuneration of directors of listed firms, http://eur-lex.europa.eu/LexUriServ/LexUriServ.do?uri=OJ:L:2009:120:0028:0031:EN:PDF, 23.06.2014.

European Commission (2009). IP/09/673 Press release of European Commission from 29th April 2009. Directors' pay: Commission sets out further guidance on structure and determination of directors' http://europa.eu/rapid/press-release_IP-09-673_en.htm?locale=en. Accessed June 23, 2014.

European Commission (2010). Report on the application by Member States of the EU of the Commission 2009/385/EC Recommendation (2009 Recommendation on directors' remuneration) complementing Recommendations 2004/913/EC and 2005/162/EC as regards the regime for the remuneration of directors of listed firms.

NBK (2003). NBK Recommendations: Recommendations Issued by the Näringslivets Börskommitté (the Swedish Industry and Commerce Stock Exchange Committee), Företagsjuridik Nord \& Company, 2003.

SCGB (The Swedish Corporate Governance Board). (2015). The Swedish corporate governance code. Stockholm: Kollegiet for svensk bolagsstyrning.

Katarzyna Cieślak $\mathrm{PhD}$, is an assistant professor at the Department of Business Studies, Uppsala University, Sweden. She is also an affiliate member of the Association of Chartered Certified Accountants (UK). Her current research is in the field of corporate governance and financial reporting, and focuses on board dynamics, including gender issues, ownership structure, and executive compensation. 